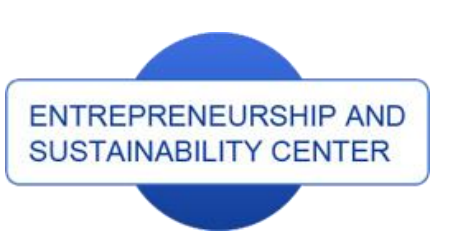

Publisher

http://jssidoi.org/esc/home

\title{
CONFLICT RESOLUTION APPROACHES TOWARDS SMART SUSTAINABILITY OF INTERNAL RELATIONS*
}

\author{
Rastislav Kazanský1, Vladimír Andrassy ${ }^{2}$ \\ ${ }^{1}$ Faculty of Political Science and International Relations Matej Bel University, Kuzmanyho 1, 97401 Banska \\ Bystrica, Slovak Republic \\ ${ }^{2}$ The Armed Forces Academy of General Milan Rastislav Stefanik, Demanova 393, P.O.Box 9, 03106 Liptovsky \\ Mikulas, Slovak Republic
}

E-mails: ${ }^{1}$ rastislav.kazansky@umb.sk, ${ }^{2}$ vladimir.andrassy@aos.sk

Received 15 August 2018; accepted 15 December 2018; published 30 March 2019

\begin{abstract}
Each country has to be able to develop efficient economic policy, facilitating sustainable economic development of national economy. In order to devise such policy, development patterns of a country have to be known, external threats indicated and various scenarios of their impact has to be foreseen, their impact forecasted and discussed (Tvaronavičiené, 2018). Conflicts within the environment of international relations, whether these are domestic or interstate, have become one of the most intensely perceived security problems of the contemporary world. Their nature is usually violent, accompanied by human casualties, which may escalate to humanitarian crises and may cause enormous material, population and ecological damage. Regions in conflict are the source of population migration, increasing pressure and they become a suitable environment for the formation of radical and terrorist groups. The destructive force of conflicts causes an economic decline of countries and, thus, increases the differences between stable regions and countries and those regions and countries with ongoing conflicts. The resolution and prevention of conflicts within international relations is a multidisciplinary approach, which draws on psychology, sociology, mass communication, development studies, studies of international institutions and political science, security studies and, in particular, on the study of international relations. In this contribution we present proposal of conflict resolution approaches due to the smart sustainability in the content of social systems, especially in international relations.
\end{abstract}

Keywords: conflict; security; negotiation; facilitation; mediation; arbitration; adjudication; conflict resolution

Reference to this paper should be made as follows: Kazansky, R.; Andrassy, V. 2019. Conflict resolution approaches towards smart sustainability of internal relations, Entrepreneurship and Sustainability Issues 6(3): 1468-1484. https://doi.org/10.9770/jssi.2019.6.3(29)

*This research was supported by the outcome of the project "Analysis and Simulation of Information and Security Threats Workplace (PASIBO)”, which has received funding from the European Union's Grant Agreement Number OPVaV-2015/1.1/03-SORO, ITMS code 26210120044.

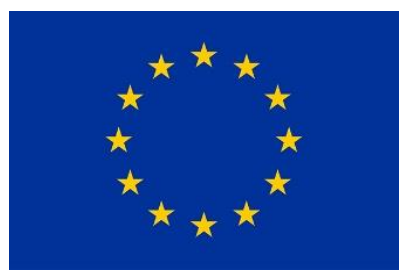




\section{Introduction}

The fundamental changes in the global security environment, emerging after the end of the Cold War and the fall of bipolarity, have brought, besides their uncontested positives, also numerous negatives. While the positive side of this process has become manifest mainly in and through the removal of the threat of war between two antagonistic military-political groupings - the North Atlantic Treaty Organization and the Warsaw Pact, as well as the threat of a possible nuclear missile apocalypse, the negative side has increasingly manifested itself through diverse forms of various security threats, for example terrorism, organized crime, massive illegal migration, etc. The emergence of new, especially asymmetric security threats and their proliferation, combined with massive transformations in the political, economic, social, environmental and technological fields, have provoked in the world not only integrating but also disintegrating tendencies (Ivančík, Nečas, 2017; Becerra-Alonso et al, 2016), that have resulted in many crisis and conflicts (predominantly civil wars) throughout the world. Conflict is the most intense security issue that has so far not a uniform definition (Kazanský, Šestáková, 2017).

The main subject of this part is to briefly outline how conflicts are solved within international relations. When considering conflict resolution as an individual branch, we proceed from various scientific disciplines such as international relations, peace research, security studies, etc. The main objective of conflict resolution is a purposeful, constructive and productive transformation of conflicts, aimed at minimizing the use of violence, overcoming antagonisms between the sides of conflicts and maintaining the conflict solving in a long-term perspective. Conflict resolution also involves creating short-term and long-term strategies, studying the interests and goals of the participants, their behaviour, way of negotiating, their surroundings and the environment of the conflict, third parties involved, etc. Other studied factors are the way agreement can be reached and realized, and also long-term maintenance of the agreement. An important feature of conflict resolution is also creating ways and methods of effective prevention of conflicts, both violent and non-violent. The starting point for an effective prevention and resolution are the research and analysis of conflicts, their characteristics and individual phases that are defined in the next part.

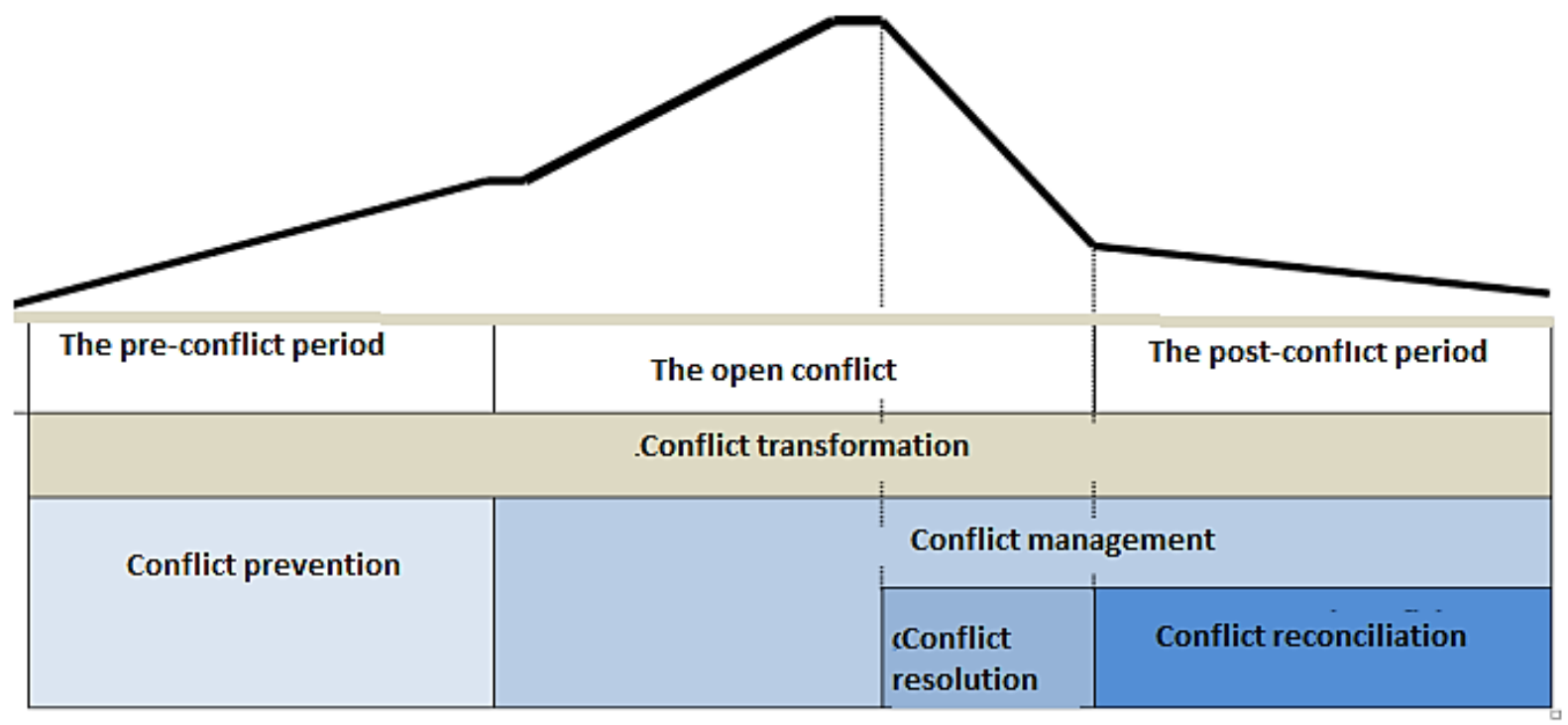

Fig. 1. Continuity of actions associated with conflict resolution Source: Hofreiter, 2008

To analyse conflicts correctly we must recognize differences between the terms ending the conflict and resolving the conflict. Not all the ended conflicts can be considered resolved. From the standpoint of the conflict solving 
process, we must determine all the actions and processes that are part of ending and resolving. Actions that take place within the development of conflicts are shown in figure 1. In course of the conflict development phases, we can identify and define these actions (Hofreiter, 2008):

1) conflict transformation,

2) conflict prevention,

3) conflict management,

4) conflict resolution,

5) conflict reconciliation,

6) building peace.

Conflict transformation is a complex term representing activities and processes that lead to changes of various typical attributes of conflicts by means of solving the original causes of a particular conflict during a longer period of time. This term is used to determine both the process of conflict and its ending. It includes processes such as conflict prevention, conflict resolution and it is also related to conflict reconciliation.

Conflict prevention represents the activity before the formation of a conflict. Its goal is to identify the situation and circumstances which could escalate into a violent conflict, reduce the amount of emerging disputes, prevent escalation into violence and eliminate the causes of disputes before there is a possibility for an armed encounter. Conflict management includes actions, which lead to limiting, moderating and suppressing an open conflict, so that negative and disruptive displays can be prevented. Its goal is to end the conflict in a way that prevents escalation or repeated violence (Mischnick, 2007).

Conflict resolution can be generally characterized as an activity, which is primarily oriented on defining and studying the causes of a conflict. Another goal of conflict resolution is an examination of progress of the relationships between the parties involved. The goal is to reach agreement between the sides of the conflict and settle the problem, so that it would not become a basis for new disputes in the future. Waisová defines conflict resolution as a social situation, in which the participants of an armed conflict voluntarily choose to coexist peacefully or to solve the basic causes of incompatibility of their interests so that the violence can be stopped. This definition only concerns armed conflicts (Waisová, 2005). Hofreiter defines conflict resolution as a complex term indicating the fact that deeply rooted causes of a conflict have already been identified and transformed. As a result, the behaviour of the parties involved is not violent any more, the views are not hostile and the structure of the conflict has changed (Hofreiter, 2008).

\section{Methods of conflict resolution}

There are various approaches to conflicts, but only 4 basic ways of conflict resolution at the level of behaviour:

1) escape, which represents passive approach towards the conflict,

2) attack, which can be verbal, but might escalate into physical aggression,

3) manipulation, when participants try to influence their opponent by various means,

4) non-violent way of satisfying the participant's needs, which is straightforward and open.

The concept of conflict resolution prefers the last, non-violent possibility. The goal is to solve the conflict constructively, so that the requirements of all the parties involved are met. In this context, psychology recognizes the cognitive approach and works with functions such as the thought process, will, memory, rational choice. It is based on the fact that in social society conflicts do not occur. Philosophical approach prefers the idea of nonconflictual coexistence. In the case where a conflict emerges, the parties involved should not avoid and deny it, but at the same time, they shouldn't escalate it into a higher level. Conflicts should be dealt with in the early stages and an appropriate method of solving them must be found (Labáth, 1997). Kusá defines five basic conflict resolution methods and dependent resolution approaches (Kusá, 2005):
1) negotiation,
2) facilitation,
3) mediation,
4) arbitration,
5) adjudication. 
The goal of each conflict resolution method is to allow the participants to eliminate their emotions, rationally consider the situation, decide on certain steps and approaches and make a particular, measurable and realistic agreement with their opponents.

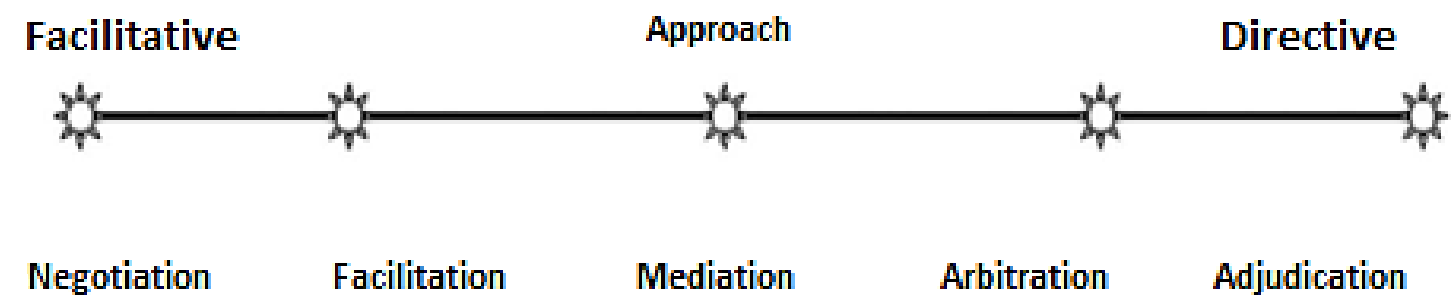

Fig. 2. Basic methods of conflict resolution Source: Kusá, 2005

Agreement based on sustainability as a harmony of all the parts with the whole is the basic goal for each of the conflict resolution methods (e. g. Tvaronavičienè, Grybaitė, Tvaronavičienė, 2009, Tvaronavičienè, Grybaite, 2012; Lankauskienè, Tvaronavičienè, 2012; Prause, Tuisk, Olaniyi. 2019).

\section{Negotiation}

The use of a conflict resolution method depends on the particular conflict stage. In the initial stage, parties involved are willing to come to an agreement and solve the conflict by means of negotiation. Sustainability in negotiations is a good balance of actions, proportionality associated with (Peleckis, Peleckiené, Peleckis, 2012):

a) actions structure of negotiator,

b) the timing of the negotiating actions,

c) compliance of behaviour to actions of opponent (partner, the interviewer).

Immediate, alive chat in negotiations offers significant opportunities to provide for the interviewer the background of your position. The fact that it is not possible to repeat the conversation encourages negotiator to seek sustainability and systematic exposure to opponent, to use all opportunities given. For this purpose, the following negotiator's positions reasoning techniques are used (Peleckis, Peleckienè, Peleckis, 2012):

- proof arguments,

- counterarguments,

- $\quad$ bluffing,

- manipulation,

- persuasion,

- $\quad$ suggestion.

Negotiation represents an informal process, during which the sides of a conflict voluntarily hold talks about the possibility of its resolution. Mutual agreement about the suggested solution is needed. The process can be formal in some cases. This depends on the approach of the parties involved. A typical feature of negotiation is the absence of any judge, mediator or a third party. See figure 3. 


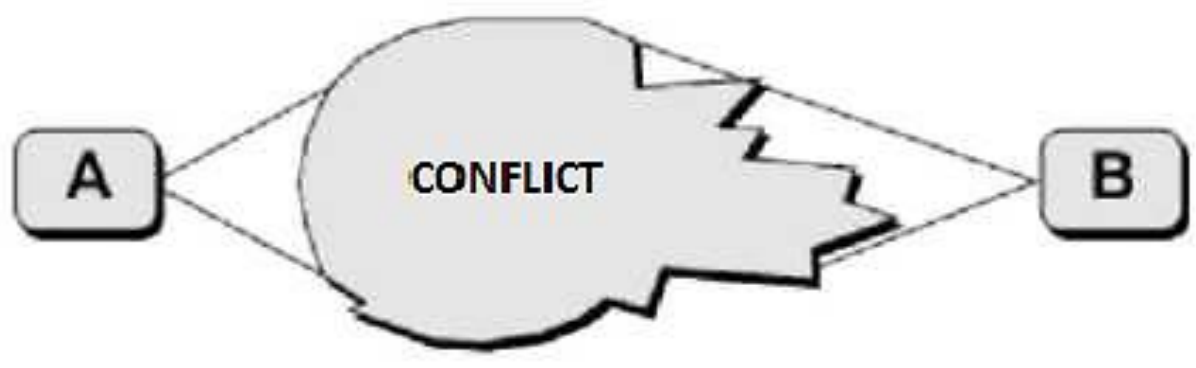

Fig. 3. Negotiation

Source: Mischnick, 2007

Negotiation is an interpersonal or inter-group approach, which can function on multiple levels (Kusá, 2005):

1) personal level,

2) organization level,

3) international (diplomatic) level.

The goal of the negotiation process is to create and build relationships, by which the participants try to come to an agreement about the issues of individual or mutual interests. Conflict participants create a direct connection - verbal, written or using a negotiator. The sides to the dispute define the subjects of discussion and decide how the dialogue will run. They also hand each other information and messages, discuss their goals, interests, possible needs and demands, create possibilities for conflict resolution and analyse their practicability.

Negotiation is a communication process and one of the participants' goals is to influence the opponent and gain benefits. The force of negotiation is defined by the ability to influence the other side's decision. The negotiation process is divided into three basic stages (Mischnick, 2007):

a) $\quad 1^{\text {st }}$ phase: Preparation. In this stage, it is essential to analyse the conflict situation and summarise all the information. The object of the analysis is also to determine interests, goals and needs of the parties involved. The next step is to consider possible results of negotiation and pick the best option available. The last part of the preparation stage is to establish contact with the opponent and mutually agree about the place and process of negotiation. This agreement involves basic rules and the object of the negotiations.

b) $\quad 2^{\text {nd }}$ phase: Interaction. In this stage, the key is to analyse the situation from various points of view and agree about an accurate definition of the problem. Interaction also represents evaluating and defining the priorities of different possibilities according to the interests and needs of parties involved, and a choice of the best alternative or combination of alternatives that satisfy the interests and demands of the parties involved.

c) $\quad 3^{\text {rd }}$ phase: Conclusion. The main goal of the negotiation process is to achieve a binding settlement between the parties involved, which would satisfy their legitimate needs. The goal is not to come to a state in which one side adjusts to the demands of the other, but to achieve a willingness of the participants to combine possibilities trying to find an adequate solution. In the case where a negotiator represents a large group, he or she must have an unequivocal mandate from this group and also the conditions of their mutual communication must be clearly stated. The conclusion stage also involves creating an action plan for the parties involved and a plan of evaluation, control and agreement.

We must stress that negotiation is considered to be one of the basic tools of international conflicts and disputes resolution. Contemporary processes of globalization affect the density of interactions between countries and societies. The frequency and depth of these interactions are causes of conflictual relationships' emergence. Subjects of negotiations are, e.g., the questions of trade policy, economic policy, investments, natural resources, environment, etc. An effort to solve the questions of war in a peaceful way, by means of international negotiations and diplomacy, has been a characteristic feature for the period since World War II. The quickly 
ENTREPRENEURSHIP AND SUSTAINABILITY ISSUES

ISSN 2345-0282 (online) http://jssidoi.org/jesi/

2019 Volume 6 Number 3 (March)

http://doi.org/10.9770/jesi.2019.6.3(29)

increasing number of international institutions in the $20^{\text {th }}$ century was another impulse for the development of negotiations. The talks between these institutions were also essential for the development of this process.

We must also stress the fact that a main correct approach does not exist. There are just less effective and more effective approaches, which differ according to different factors of the context. The importance of negotiations when solving international conflicts (inter-state, internal or civil) has been apparent in the last decades. It follows that an increased interest for this conflict resolution method is shown among the experts (Galtung, 2004).

\section{Facilitation}

If the conflict is not being solved and the participants insist on their standpoints, being unable to reach appropriate communication, the conflict escalates and its resolution is impossible without the entry of a third neutral party. In this stage of a conflict, an appropriate tool is facilitation, i.e. creating conditions that allow the participants to communicate. Successful facilitation means the negotiating environment, rules, time horizon and process of discussion, so that it is possible to overcome opinion, interest or value barriers between the parties involved (Kusá, 2005).

Facilitation is a process, which creates an environment for an effective and secure dialogue about complex issues. It is a structured method, which should simplify the negotiations despite polarized standpoints of the participants. A basic principle is to use mutual consensus in each step. Its goal does not have to solve all the disputable questions. It is considered a success is if the opponents are able to listen to each other, understand the position of one another, openly showcase their interests and describe their views of the situation.

Facilitation is used in different environments, e.g. local communities, educational institutions, corporations, etc. (Mischnick, 2007). Facilitation is a controlled negotiation with the presence of a neutral expert, who helps the participants coordinate the dialogue. The facilitator is a part of the system the conflict emerged in. He helps the sides to analyse problems, find solutions of disputes and ways of using them. The facilitator tries to make the dialogue more effective and helps find consensus, without using ultimatums. A good facilitator does not solve conflicts, but simplifies the communication. He does not intervene in the subject of discussion, but ensures its fluency and direction, allowing all the parties involved to have equal opportunities to influence it. The presence of a facilitator can be enough to direct the dialogue so that it could be successful. Facilitation can help solve the conflict or make it just a "disagreement". Then negotiation can then follow (Labáth, 1997).

\section{Mediation}

When a conflict is dynamically developing, strong polarization may occur, one side refusing to communicate with the other. In such case we distinguish separation (partial contact interruption) and isolation (complete contact interruption). In this situation, negotiation is impossible as the sides refuse to communicate. Facilitation is not possible either, because an environment for communication between the participants cannot be created. Disputes between parties that refuse to mutually negotiate can be solved by mediation. An effective solution is to involve a mediator in the talks (Labáth, 1997). The scheme of mediation can be seen in figure 4 . The term "mediation" originates from Latin mediato - arrangement. The term "mediation" in international law means any process, involving the victim and the offender of the criminal offense, who, freely and without any influence, agree to eliminate the problems, caused by a criminal dispute, acting with the help of a neutral third party named as mediator (Jefimovs, 2018).

Mediation represents an assisted negotiation. It is an organized process in which a third party with no decisive authority helps the sides of a conflict to negotiate a mutually acceptable agreement. The basic goal of mediation is creating or re-creating communication channels between the conflict participants using a mediator. This means a systematic emphasizing of communication by means of the mediator and not directly between the sides of a conflict, at least in the stages focused on history. This approach crates a communication interstage, and the opponents can then seek solutions via the mediator. If the conflict is in a stage of isolation, parties involved do not need to meet at all (Mischnick, 2007). 
Mediation functions strictly according to the principle of having permission from both sides for each step of the process. A mediator does not make individual decisions on participants' behalf, but helps the opponents find a solution on their own. In certain cases, the mediator gives impulses, propositions or formal suggestions for reconciliation of the dispute. First of all, the mediator is a "procedural expert" who helps the parties involved determine the program of negotiations, define and re-frame ideas, lead the dialogue more effectively, find a common interest and, of course, reach a mutually acceptable agreement. From the historical point of view, the original and "natural" mediators were priests, shamans, elder members of the tribe, etc., because they had the trust of the community, which is an important feature even in today's use of mediation. A mediator takes action in situations of disagreement, misunderstanding, armed attack and other disputes where considerable mistrust exists between the participants. That is why it is important for the mediator to represent a trustworthy link between the opponents. Another important feature of successful mediation is the ability to persuade (Galtung, 2007).

The mediator also has to be able to create a more productive dialogue than the conflict sides can. To achieve this, mediators help the participants with mapping the facts, show empathy and impartiality to both sides and help them create new ideas. Mediators also apply strategic abilities and use persuading to achieve a state, when the participants moderate their extreme positions (Mischnick, 2007).

The result of a targeted and successful mediation is a consensus, which the participants accept explicitly and which is satisfactory for each one of them. One of the goals of mediation is to make the individuals or groups involved in a conflict active participants of negotiations. All the sides should actively seek agreement, which is acceptable for everybody and which satisfies the goals, needs and interests of all the participants. The goal of active contribution to the mediation process is to divert attention of the participants away from other impulses, which could lead to escalation of conflicts, e.g. strikes, armed attacks, legal disputes, etc. The goal of mediation is to allow the parties involved to meet, to try to improve mutual relations and understand problems, which should lead to avoiding polarization and creating space for more discussions and negotiations. The result of a successful mediation is an agreement, confirmed by all the parties involved. The agreement should also specify the ways of how given goals have been accomplished (Kusá, 2005).

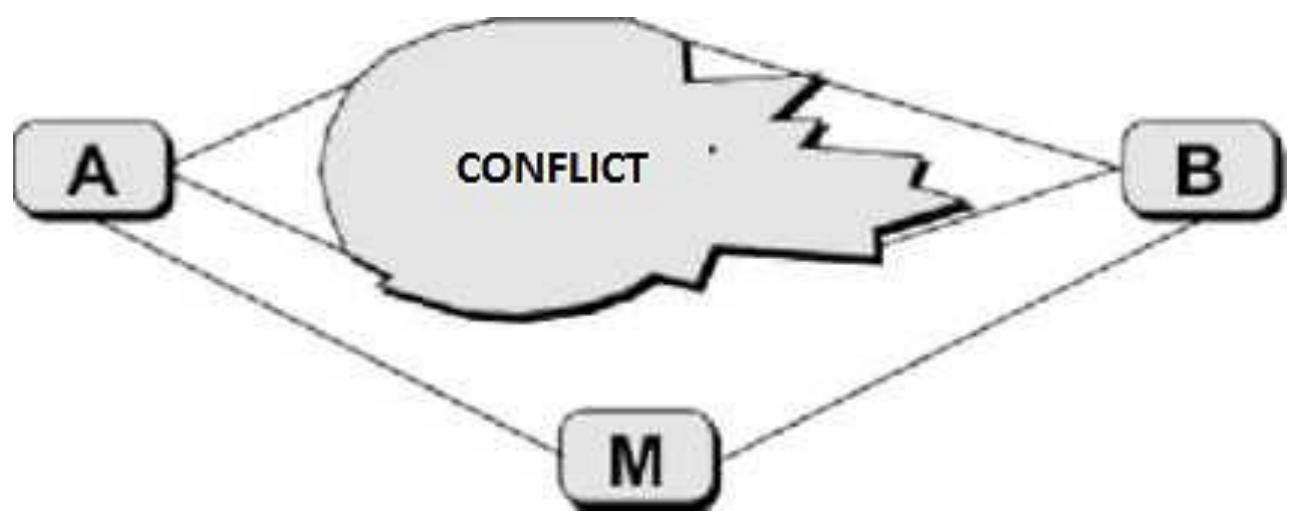

Fig. 4. Mediation

Source: Mischnick, 2007

Mediation is widely used in all kinds of discussions considering complex problems of public policy or international conflicts. In case the conflicts are seemingly unsolvable, there is still a possibility of solving them using mediation. Mediation is extremely important in long-term, deep-rooted conflicts, because solving such conflict is not possible without external help. Even in situations when it is impossible to right all the wrongs, mediation is useful for solving individual aspects of a wider conflict. 
ENTREPRENEURSHIP AND SUSTAINABILITY ISSUES

ISSN 2345-0282 (online) http://jssidoi.org/jesi/

2019 Volume 6 Number 3 (March)

http://doi.org/10.9770/jesi.2019.6.3(29)

Mediation is a highly effective method used for conflict resolution achieving a high success rate in particular cases. Use mediation variations is more effective than to apply traditional litigation (e.g. Jurkevičius, Bublienè, 2017; Šišulák, 2017; Limba, Šidlauskas, 2018; Kordík, Kurilovská, 2018).

\section{Arbitration}

Arbitration is an alternative, traditional way of dispute resolution. We divide the sides of conflicts to the winning and losing ones. Historically, disputes were most often solved by a directive approach - based on using power or authority. The resolution principle has been the same whether it was a tribal meeting of council of elders, decision of a reeve or a king. The third neutral side always used its authority to pronounce obligatory verdicts. It decided how the case would be solved according to the subject of dispute and evaluation of evidence and witnesses. It all works the same way until today. Traditional conflict resolution methods are nowadays represented by legal system, including the activities of police department and the institute of imprisonment (Kusá, 2005). An arbitrator is named - either by a court, or by other adjudicative authority. The main task of an arbitrator is to hold an interlocutory hearing of a case, evaluate the evidence, arguments and testimonies, and deliver a verdict within given competences. The arbitrator can be generally authorized to investigate, mediate, make recommendations, etc. Letting an independent, third party decide about the subject of a conflict is a tradition older than the law itself.

Arbitrational lawsuits exist in all communities and civilizations. The final verdict of an arbitration is obligatory, but in some exceptional cases may just have the nature of a recommendation. A characteristic feature of an arbitration is its voluntariness. This means that the participants should agree about the means of solving the dispute. Another typical feature is the greater possibility to influence the sides' decisions by means of a higher level of informality in front of the court of arbitration. The approach towards conflict resolution is directive. The arbitrator hears the sides of the dispute and decides the most effective possibility. Arbitration is used in different sectors, mostly in the commercial sphere, but it is also institutionalized at courts. At the international level, arbitration is a commonly used conflict resolution method, e.g. in situations after civil wars. A Arbitration tribunals were established e.g. in the countries of former Yugoslavia (The Badinter Arbitration Committee, which consisted of five constitutional court judges from the countries of the European Economic Community. The committee decided about the accession of successor states to the EEC), in cross-border disputes, e.g. between Eritrea and Ethiopia (Eritrea-Ethiopia Boundary Commission of the Permanent Court of Arbitration in The Hague), or between Slovenia and Croatia (about the Slovenian corridor to open sea) (Kusá, 2005).

Obligatory and most often used arbitration mechanisms are:

a) Ombudsman - public human rights protector. The foundations for this institution were laid in Sweden, back in the 18th century. Since then, it has spread into more than 70 countries around the world. The role of an ombudsman is not only administrative. The institution of ombudsman serves as a tool to solve conflicts in other than judicial way (Kusá, 2005). "The Public Protector of Rights is an independent body which, protects basic rights and freedoms of natural and legal persons in proceedings before public administration bodies and other bodies of public authority, if their conduct, decision-making, or inaction, is in conflict with the legal order" (Constitution of the Slovak republic, 1992, art. 151a).

b) Court of arbitration - Arbitration represents an out-of-court settlement of disputes assisted by judicial officials. The goal of the arbitration courts concept was to decrease the number of lawsuits and accelerate the decision-making process in particular cases. Before the beginning of arbitration, the opponents sign an arbitrational contract, where competences of the court of arbitration are defined. Courts of arbitration use a combination of both public and private law. The final verdict is obligatory and in this case no corrective devices are permissible. The nature of arbitration is voluntary and it represents an alternative method of conflict resolution.

The institute of ombudsman along with the courts of arbitration represent a relatively respected authority in democratic countries. Both institutions are consensual methods of conflict resolution, where the final decision is pronounced by a third party (Kusá, 2005). 
Mediation-arbitration hybrid (also referred to as med-arb) is a relatively new alternative dispute resolution method known since the 1970's. It is argued that this method combines the advantages of both mediation and arbitration and eliminates most of their disadvantages. In recent years a lot of variations of mediation and arbitration applied together appeared (Kaminskienè, Žalënienè, Tvaronavičienè, 2014):

- $\quad$ at first mediation, if unsuccessful, then arbitration; arbitration begins but certain degree of mediation is allowed:

mediation is applied to deal with particular issues, arbitration with others,

- mediation begins, then arbitration is addressed to the issues on which agreement was not reached, then mediation re-applied;

the mediation is carried out and if there is a failure, then the mediator is asked for an "advisory opinion", which is mandatory, unless any of the parties within a period of time vetoes it.

Med-arbitration, as we have seen from the above, combines many possible variations and is quite flexible procedure. In principle, both methods of alternative dispute resolution (mediation and arbitration) in terms of sequence and procedural specificities depend on a will and general consensus of the parties, and on the selected mediator's practice as well (Kaminskienè, Žalėnienè, Tvaronavičienè, 2014).

This controversial hybrid method combines the ultimate decision-making guarantee (this is achieved through arbitration), and the subtle management of delicate issues, which ensures mediation. Basically med-arbitration eliminates the biggest disadvantage of mediation - final decision is guaranteed and there is no need to litigate (Kaminskienè, Žalènienè, Tvaronavičienè, 2014).

\section{Adjudication}

It represents a form of conflict resolution with the highest obligation level. It involves deciding about the subject of dispute by a third party, which has the competence to deliver obligatory verdict. Adjudication can take place in an out-of-court way, but a judicial lawsuit is its most common form. It is a structured and formal process, which is not based on voluntary participation. It is a situation, when one side is the winner of the lawsuit, and the other loses. Adjudication is based on competition between the opponents.

It represents one of a few involuntary forms, where the opponent cannot choose a different way of dispute resolution, neither avoid it. In the stage of a higher conflict escalation level a lawsuit can be unconditional and beneficial. Adjudication is a legal process, in which the lawsuit is judged according to the evidence and argumentation of advocates, while the rights and obligations of the sides of a conflict are taken into account.

The trial is highly structured and it follows the law and exact procedural rules. The plaintiff, who initiates the lawsuit, demands legal rectification of the situation. If successful, the judge decides in favour of the plaintiff and pronounces a verdict, which contains exercise of the law, right for compensation, punishment and sanctions of the opponent, and a court order prescribing or forbidding particular action or declarative approach of the opponent, all to prevent the emergence of more conflicts (Kusá, 2005).

\section{Alternative conflict resolution}

Based on conflict research, it is obvious that disputes are best solved during their latent phase, if there is no escalation. However, it is not possible to do in all cases. Because of this, it is also necessary to define alternative methods of resolving conflicts that have already erupted. The methods of dealing with conflict situations, as well as individual conflicts, differ. We can split them up into several groups.

1) The method of violence - violent suppression of conflicts.

2) Escaping or avoiding the conflict.

3) Game theory, as a way of resolving conflict situations. 
ENTREPRENEURSHIP AND SUSTAINABILITY ISSUES

ISSN 2345-0282 (online) http://jssidoi.org/jesi/

2019 Volume 6 Number 3 (March)

http://doi.org/10.9770/jesi.2019.6.3(29)

\section{The method of violence}

This is an extreme way of conflict resolution where one of the parties involved in the conflict shows an evident high degree of preparedness. The basis is the determination or belief that force or the threat of force needs to be used in order to achieve one's interests and needs. The objectives of violent conflict suppression are, for example, (Hofreiter, 2008):

a) forcing conflict resolution, if the parties involved don't address it themselves,

b) preventing or punishing aggression against a sovereign state,

c) restoring a legitimate government, which was illegally overthrown,

d) preventing the supplying of weapons to the conflict region,

e) protection of the population against genocide and other violent acts, committed by their own government or as a result of an internal conflict,

f) restricting the access of the parties involved to resources that would allow them to continue or escalate the conflict,

g) protecting the democratic regime against internal and external threats.

It is necessary to lay down certain conditions for using a method in which a conflict is violently suppressed. If one party has more resources and a decisive superiority of forces, it is possible for them to use this superiority to their advantage when dealing with the conflict. The need for an immediate solution to the dispute, in the event of an emergency situation, may be another case (e.g. the deployment of the armed forces and the police in situations where it is necessary to separate the opposing parties). Another example is the need to adopt and enforce an unexpectedly violent (but necessary) resolution of the dispute, which the opposing party will see as negative. The condition in the choice of a violent conflict resolution occurs in the case of a conflict situation which could cause significant material or humanitarian damage, or in the event that the measures are associated with the provision of vital interests. In this case, a violent settlement of the dispute is seen as legal and in accordance with applicable law. In the case of obvious destructive activities which threaten a party involved (e.g. the state) and its interests, the method of violence is adequate (for example during violent demonstrations of anti-globalists, eco-activists, during riots, violation of public order, destroying or damaging of property).

The deployment of regular armed forces, during Peace Support Operations (PSO), to areas with conflicts may also be considered as a violent solution to violent domestic and international conflicts (Ivančík, Jurčák, 2013). PSO are multifunctional operations, co-ordinated by military and also civilian organisations on the basis of impartiality. They are divided into: operations for conflict prevention, peace-enforcement operations after the emerging of a conflict, peace-keeping operations, peace-building operations and humanitarian operations (Hofreiter, 2008). It is the violent resolution of a dispute by a third party, which is usually represented by the international community, which has an armed military force with an appropriate mandate to settle the conflict.

Another category of operations which use the deployment of military forces are the so-called Peace-enforcement operations (PEO). The consent of the parties involved in the conflict is not required to begin this type of operation. Such activities represent violent operations, consisting of the deployment of armed units in a direct struggle to protect the civilian population affected by the conflict. Its goal is to eliminate armed violence and establish peace. Within the framework of the measures defined in the Charter of the United Nations, peaceenforcement is the highest form of involvement of international peace-enforcement units in conflicts.

If the situation is sufficiently stabilized, peace-enforcement activities are replaced by a peacekeeping activities. This category includes peacebuilding operations and peacemaking operations. The mandate of the units used in such operations contains provisions identical to those of peace enforcement because, in the case of stabilisation it is, in some cases, necessary to use force in order to maintain a peaceful situation. These units have a mandate under Chapter VI, and VII of the Charter of the United Nations. In some cases, their mandate is defined in international agreements (Hofreiter, 2008).

The use of force or the threat of its use is an extreme, though not always effective, final solution to the conflict. Coercion of the opponents in the conflict to end their violent acts against each other does not mean the removal 
ENTREPRENEURSHIP AND SUSTAINABILITY ISSUES

ISSN 2345-0282 (online) http://jssidoi.org/jesi/

2019 Volume 6 Number 3 (March)

http://doi.org/10.9770/jesi.2019.6.3(29)

of the subject of the conflict and the causes of the dispute. It is not impossible for the conflict to begin anew, if the power causing its forced cessation stops being active.

\section{Escaping - avoiding the conflict}

If one of the parties involved in the conflict is not sufficiently prepared and does not have the ability or the means to solve the dispute. They then usually use the method of escaping or avoiding the conflict. In this case, the party involved is not able to deal with the situation and communicate with its opponent about the possibilities of settling the dispute. From the perspective of one of the parties involved, escaping from the conflict is a relatively easy way of resolving it. The essence is ignoring the conflict situation, denying it exists or leaving the area where the conflict takes place. A party involved in the conflict decides not to take any constructive steps towards resolving or changing the situation.

In the initial stage of the investigation of this alternative of conflict resolution, it may seem negative because of the parties' passive approach. With a deeper analysis we can also define some positive aspects and advantages. For example: escaping or avoiding the conflict is a quick way of dealing with the situation, and it does not require intellectual, material or large financial resources; this method makes it possible to avert or delay the conflict, if it's irrelevant to or not interesting enough for one of the parties involved. The downside of this approach is that an escalation of the conflict may occur because the root cause of the conflict is not removed but preserved. Delaying the resolution of the dispute may lead to a deepening and escalation of the conflict, instead of its resolution.

The use of the method of escaping or avoiding a conflict is subject to a number of factors. The method is justified if there is another relevant and constructive conflict that needs to be addressed as a priority and, if not solved, does not result in negative consequences. If the party fails to address (or avoids) the unimportant causes of existing conflicts, it allows the party to save their resources and strength and focus on important issues and disputes. The method of escaping is also used in a situation where the opponent does not have sufficient information and, given the seriousness of the conflict, acquiring it would be extremely complicated and disadvantageous in terms of cost and resources. Another example of this method's use is when the opponent has great superiority, which he can use to achieve a quick victory in the open rivalry.

Certain features of behaviour and specific activities of the parties involved are typical for this method. They include, for example, hiding information necessary to resolve the dispute in order to prevent the escalation of the conflict as a result of a leak of sensitive, strategic information. Another typical feature is the use of a variety of arguments to delay the resolution of disputes and problems that are the causes of the conflict. A characteristic manifestation of behaviour is refusing to acknowledge that the causes of the conflict truly exist and relying on the dispute being resolved without the active presence of the parties involved (Hofreiter, 2008).

\section{The Game Theory}

It represents a formal, rational, mathematical method of the study of decision-making in conflict situations. It analyses the communication and decision-making of the parties involved in negotiations and the conflict itself. It applies the "MINIMAX" principle (minimizing costs and maximizing profits) into the theory of decisionmaking. The basis of this principle is that every party has correctly defined objectives, will act according to the rules and means given, and will not wrongly choose their goals. There are two approaches in the game theory:

a) cooperative games, where the parties involved communicate and make agreements relating to choosing their strategies,

b) non-cooperative games, where reciprocal agreements are not possible and communication may or may not exist (Drulák, 2010).

The game theory is divided into three basic models:

1) a game with opposing interests,

2) a game with identical interests, 
a game with mixed interests.

Game with opposing interests.

In case of games with opposing interests, we can talk about a zero-sum game. The parties involved mobilized their resources and forces in order to enforce their interests and goals and to prevent their own defeat and failure. The interests of the opponents in the conflict are in contradiction and each opponent tries to gain absolute superiority over the others, and seeks to force them to deal with interests, which are contrary to their own. In the game with opposing interests, the result must be a complete defeat of one of the parties involved. One party may profit only at the expense of the other (Krejčí, 2014). This non-cooperative strategy is shown in Chart 1.

This strategy is used in conflicts, where the parties involved aim towards a confrontation and are in a conflict to gain specific positions and maintain them. The characteristics of this approach are (Hofreiter, 2008):

- $\quad$ the opposing parties in the conflict seek to maximize the realization of their objectives, regardless of the objectives and interests of their opponent,

- $\quad$ the goal of the parties is to uncompromisingly refrain from any concessions, or to hinder the loss of their gained position,

- $\quad$ opponents wish to remain on their achieved or gained positions and aim to defend them without compromise,

- $\quad$ the conflicting issues form the borderline factors of the conflict, differences between the opposing parties (there is no willingness to change these differences),

the behaviour and activities of the opposing parties are aimed at the opponent, his discredit, elimination, and not towards the resolution of the dispute.

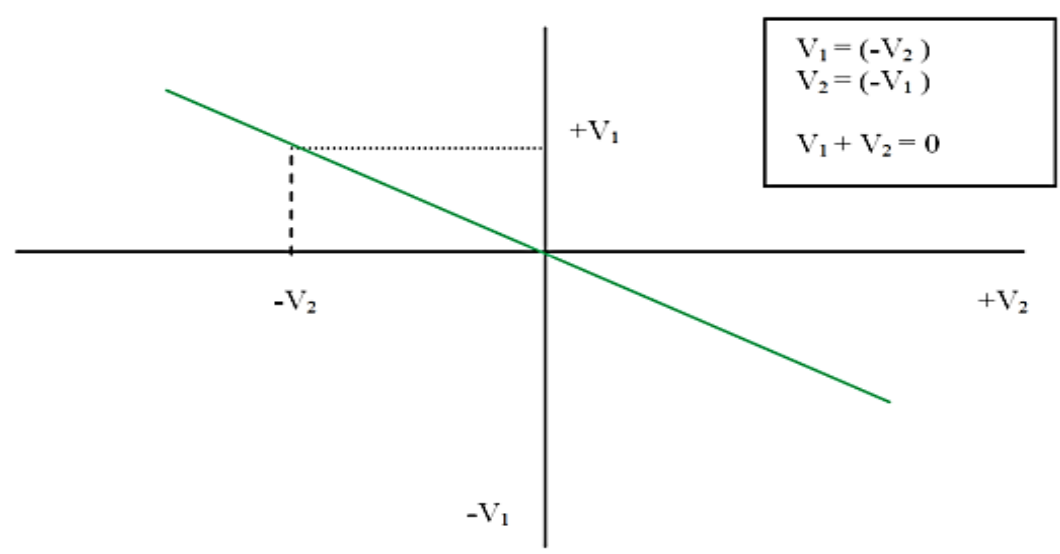

Chart 1. Vector of profit of the game with opposing interests Source: Krejčí, 2014

\section{Game with identical interests}

The second model of the game theory is the game with identical interests, the non-zero-sum game, which is a cooperative way of resolving conflicts. In this case, the parties involved are open and willing to accept unilateral concessions or to adapt. Adapting does not mean a clear victory for the opposing parties, but neither is it a loss. A party that retreats from its position will partially be subject to loss, but it will also gain values, or keep its positions which it maybe would have lost during an ongoing dispute. A graphical representation of the game with identical interests is shown in Chart 2. 


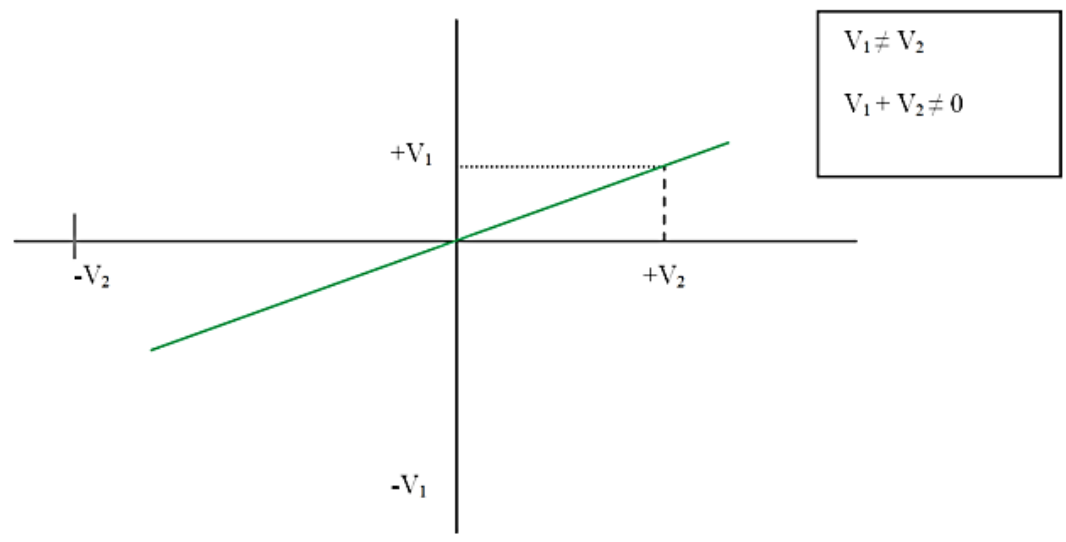

Chart 2. Vector of profit of the game with identical interests Source: Krejčí, 2014

The following types of conflict situations typically use the game with identical interests (Hofreiter, 2008):

- An obvious error committed by one of the parties involved in the conflict becomes apparent during the conflict. Escape is impossible, as is using force to solve it. For an opponent who has committed the error (such as incorrect, incomplete or misleading information), it is an alternative, which they can use to end the conflict with honour.

- If the planned concessions are too severe for one of the parties involved and is incomparable with their relevance to the second party, it is possible to adopt smaller, less significant concessions. This will eliminate the possibility of the conflict escalating and also saves the strength and resources of the opponents.

- If there are other major crisis situations which may occur in the near future and which will require the parties to conserve strength and resources. Partial concessions allow the diverting of attention from solving irrelevant problems, saving resources and focusing on averting a possible danger or expected crisis situation (e.g. in anticipation of a war, it is beneficial to solve smaller conflicts, even at the price of having to take concessions and, thus, gain the support of potential allies for the next conflict). Concessions should be taken whenever their refusal could lead to bigger losses and damage, or other disadvantages for a party in the conflict.

\section{Game with mixed interests}

The third method of the game theory is the game with mixed interests, or a non-zero-sum game, which is a cooperative method. This method is one of compromise during conflict resolution and of mutually advantageous cooperation. When using this method, the parties involved will have their interest and needs satisfied adequately and will gain the same benefits and the same losses. This method is displayed in Chart 3.

A compromise represents a kind of mutual consent, based on the mutual correction of the positions of both parties in relation to solving the issue and on finding a mutually advantageous position against the issues in question (Hofreiter, 2008).

The above described method may be a reliable basis for a long-term cooperation. It is most commonly used in democratic societies and it is considered to be a classic and model way of resolving conflicts. It satisfies the needs of both parties, due to a series of mutual concessions and mutually beneficial agreements. 


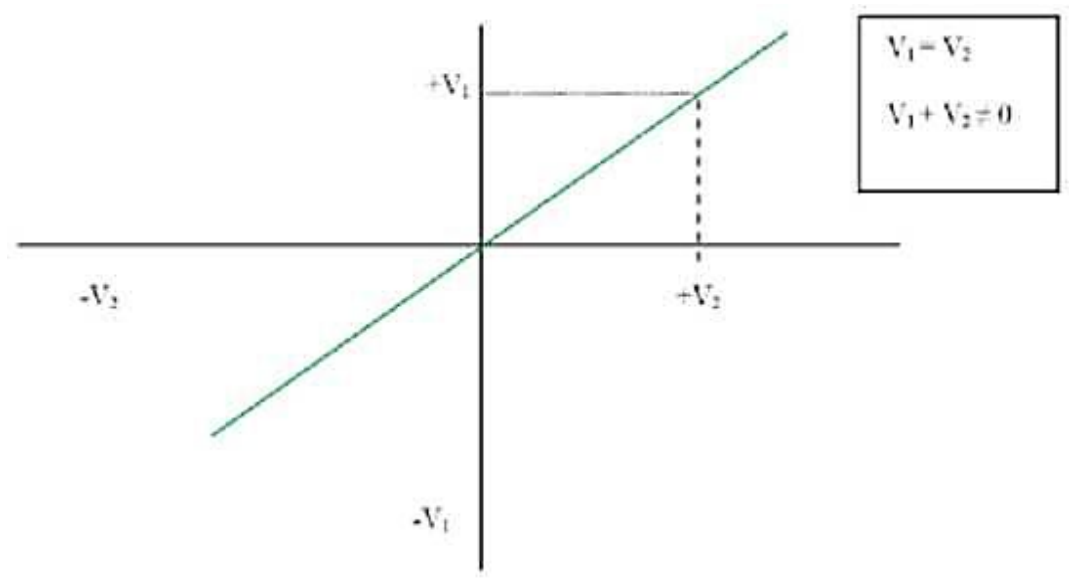

Chart 3. Vector of the game with varied interests Source: Hofreiter, 2008

Mutual conversations, discussions or negotiations, which aim to establish the common interests of the parties involved, are important when using this method. The negotiations conducted in order to reach a mutual agreement or compromise of opinions about solving the disputing issues, are conducted while respecting the interests of the parties involved.

This method assumes that the parties involved in the conflict will show a mutual openness toward positive cooperation. Prerequisites for a successful compromise solution to the conflict are, for example (Hofreiter, 2008):

- The parties involved analyse the issues and seek solutions and, at the same time, demonstrate partnership instead of rivalry.

- $\quad$ The parties involved in conflicts search for mutually beneficial variations of dispute resolution.

- In order to achieve a compromise, it is necessary to understand the opinion of the opposing party and accept alternatives in the search of a compromise solution.

- The final consensus must respect and meet the interests and requirements of all parties involved in the conflict to a maximum extent.

\section{Conclusions}

The resolution and prevention of conflicts is most commonly understood as a part of the study of international relations, which touches upon the aforementioned disciplines. The study, analysis, and research of the theory and practice in the field of conflict resolution and prevention has had its place within the framework of international relations on a global scale for several years now. However, inside of the Slovak academic and professional environment, these issues have been established only recently. This fact made us choose these issues as the subject of our work. This work may be used in the study of several scientific disciplines but mainly when studying the issues of conflict prevention and resolution within the context of international relations.

The goal of this publication is to provide a basic synthetic theoretical analysis of conflicts, methods employed to resolve them and the ways in which they may be prevented. The work is an introduction to these issues. It attempts to include a wide range of topics dealt with by the study of conflict resolution and prevention. The included deeper analysis of the issue of conflict prevention is a key part of the work. Emphasis is put on the theory and practice of conflicts, due to the importance of conflict escalation prevention in the pre-conflict phase, the phase of conflict transformation and during the process of post-conflict reconstruction. Conflicts became more dynamic in the 21 st century. This change occurred not only with the parties directly involved in conflicts, but also the parties involved in the resolution of conflicts, where we can find many different units, in addition to states. Because of this, the bulk of the work is focused on conflict prevention and resolution with the use and 


\section{ENTREPRENEURSHIP AND SUSTAINABILITY ISSUES}

ISSN 2345-0282 (online) http://jssidoi.org/jesi/

2019 Volume 6 Number 3 (March)

http://doi.org/10.9770/jesi.2019.6.3(29)

participation of national, regional and supranational parties involved. However, the current dynamics of international relations moves the examined issues forward too rapidly, which is why the work is a reflection of the state of events, which were current during the preparation and implementation of submitted facts.

\section{References:}

Alazawi, H.; Nečas P. 2016. Modern and classic diplomacy in political crisis communication management, Journal of Management Klaipeda: Klaipeda University Press, 28(1): 31-34. ISSN 1648-7974

Becerra-Alonso, D.; Androniceanu, A.; Georgescu, I. 2016. Sensitivity and vulnerability of European countries in time of crisis based on a new approach to data clustering and curvilinear analysis, Administratie si Management Public (27): 46-61.

Bolečeková, M.; Hoscheková. D. 2011. The impacts of migrations on national identity and citizenship In Identités, citoyennetés et démocratie: 20 ans aprés. In Conférence internationale de Charleroi. Bruxelles: Bruylant,. s. 173-183. ISBN 978-2-8027-3085-9.

Drulák, P. 2010. Teorie mezinárodnich vztahú, [Theory of international relations] Praha: PORTÁL, p. 224, ISBN 978-80-73677-21-3.

Galtung, J. 2004. Transcend and Transform-An Introduction to Conflict Work. London: PLUTO PRESS, p. 198, ISBN 0-7453-2255-7.

Grega, M.; Bučka, P. 2013. Cvičenia krízového manažmentu nevojenského charakteru v praxi [Non-military-style crisis management exercises in practice]. In: Riešenie krízových situácií prostredníctvom simulačných technológií. Zborník vedeckých prác z medzinárodnej vedeckej konferencie. Liptovský Mikuláš: Akadémia ozbrojených síl gen. M. R. Štefánika, 2013. s. 38-45. ISBN 978-80-8040-481-9.

Hofreiter, L. 2008. Teória a riešenie konfliktov [Theory and conflict resolution]. Liptovský Mikuláš: Akadémia ozbrojených síl generála M. R. Štefánika, p. 206, ISBN 978-80-8040-347-8.

Hreha, L. 2017. Vplyv extrémizmu na trestnú politiku štátu [The impact of extremism on the criminal policy of the state]. In: Národná a medzinárodná bezpečnost' 2017, 8. medzinárodná vedecká konferencia. Liptovský Mikuláš: Akadémia ozbrojených síl generála Milana Rastislava Štefánika. ISBN 978-80-8040-551-9.

Ivančík, R.; Nečas, P. 2017. Towards Enhanced Security: Defence Expenditures in the Member States of the European Union, Journal of Security and Sustainability Issues 6(3): 373-382. https://doi.org/10.9770/jssi.2017.6.3(4)

Jefimovs, N. 2018. Evaluations of security measures: the peculiarities of the application of mediation in the area of resolving criminal legal conflicts, Journal of Security and Sustainability Issues 8(1): 79-86, https://doi.org/10.9770/jssi.2018.8.1(7)

Ivančík, R; Jurčák, V. 2013. Peace Operations of International Crisis Management. Ostrowiec Sw.: Wyzsza Szkola Biznesu i Przedsiebiorczosci, p. 182, ISBN 978-83-936652-6-6.

Jurkevičius, V.; Bublienė, R. 2017. Towards sustainable business relationships: ratification doctrine in the case of unauthorised agency, Entrepreneurship and Sustainability Issues 5(1): 72-90 https://doi.org/10.9770/jesi.2017.5.1(6)

Kaminskienė, N.; Žalėnienė, I.; Tvaronavičienè, A. 2014. Bringing sustainability into dispute resolution processes, Journal of Security and Sustainability Issues 4(1): 69-77 http://dx.doi.org/10.9770/jssi.2014.4.1(6)

Kazanský, R; Šestáková, L. 2017. Teoretické východiská skúmania bezpečnosti [The theoretical basis of safety research]. In: Bezpečnostné fórum 2017. Banská Bystrica: FPVaMV UMB, pp. 180 - 185.

Kollár, D. 2014. Strategický a krízový manažment: trendy a koncepcie [Strategic and Crisis Management: Trends and Concepts] In: Interpolis'14: zborník vedeckých prác, medzinárodná vedecká konferencia doktorandov a mladých vedeckých pracovníkov, Banská Bystrica, 2014, s. 230-234. ISBN 978-80-557-0863-8, s. 52-53

Kováčik, B.; Ondria, P. 2009. Mierové riešenie konfliktov z hl'adiska teórii liberalizmu. [Peaceful resolution of conflicts in terms of liberal theory] In: Bezpečnostné fórum '09. Banská Bystrica: FPVaMV UMB, pp. 94 - 101.

Kováčik, B. 2012. La crise de la démocratie In Citoyennetés, voisinages et minorités en Europe. In international conference on citizenship and nationalities in Europe, Banská Bystrica - Bruxelles : Bruylant. s. 19-25. ISBN 978-2-8027-3568-7.

Kordík, M.; Kurilovská, L. 2018. Intra group compliance agreement as a tool to manage the risks in the daughter companies, Entrepreneurship and Sustainability Issues 5(4): 1008-1019, https://doi.org/10.9770/jesi.2018.5.4(21) 
ENTREPRENEURSHIP AND SUSTAINABILITY ISSUES

ISSN 2345-0282 (online) http://jssidoi.org/jesi/

2019 Volume 6 Number 3 (March)

http://doi.org/10.9770/jesi.2019.6.3(29)

Krejčí, O. 2014. Mezinárodní politika [International Politics]. Praha: EKOPRESS, p. 804, ISBN 978-80-87865-07-1.

Kusá, D. 2005. Riešenie konfliktov. Bratislava: Mirius, 29. Retrieved from http://www.equalslovakia.sk/fileadmin/user_upload /projekty/27_1.2_Riesenie\%20konflik tov\%20I.pdf

Labáth, V. 1997. Konflikty: Hrozba alebo výzva? [Conflicts: Threat or challenge?] In: Manažér, II. Retrieved from http://www.ibispartner.sk/sk/komunikacia-a-motivacia/168-konflikty-hrozba-alebo-vyzva

Lankauskienė, T.; Tvaronavičienè, M. 2012. Security and sustainable development approaches and dimensions in the globalization context, Journal of Security and Sustainability Issues 1(4): 287-297. https://doi.org/10.9770/jssi.2012.1.4(5)

Limba, T.; Šidlauskas, A. 2018. Peculiarities of anonymous comments' management: a case study of Lithuanian news portals, Entrepreneurship and Sustainability Issues 5(4): 875-889 https://doi.org/10.9770/jesi.2018.5.4(12)

Lošonczi, P. 2016. Slovensko a jeho reakcia na medzinárodný terorizmus [Slovakia and its response for international terrorism]. In: Spoločnost' proti terorizmu. Plzeň: Aleš Čenek, 2014. S.133-141. ISBN 97880-7380-546-3.

Mischnick, R. 2007. Nenásilná transformácia konfliktov [Nonviolent Transformation of Conflicts]. Manuál pre tréning trénerov. Bratislava: Don Bosco, p. 164. Retrieved from http://www.trainingoftrainers.org/img/manual_sk.pdf

Peleckis, K.; Peleckienè, V.; Peleckis, K. 2012. Implementation of sustainability principle into negotiations: substantiation positions‘ of negotiator, Journal of Security and Sustainability Issues 2(2): 55-67 http://dx.doi.org/10.9770/jssi.2012.2.2(6)

Prause, G.; Tuisk, T.; Olaniyi, E.O. 2019. Between Sustainability, Social Cohesion and Security Regional Development in North-Eastern Estonia, Entrepreneurship and Sustainability Issues 6(3): 1135-1154. http://doi.org/10.9770/jesi.2019.6.3(13)

Rajda, Z.; Jakabovič, Š. 2017. Některá opatreni Evropské unie v boji proti terorismu [Some EU measures in the fight against terrorism]. In: Národná a medzinárodná bezpečnost' 2017, 8. medzinárodná vedecká konferencia. Liptovský Mikuláš: Akadémia ozbrojených síl generála Milana Rastislava Štefánika, 2017. ISBN 978-80-8040-551-9.

Šišulák, S. 2017. Userfocus - tool for criminality control of social networks at both the local and International level, Entrepreneurship and Sustainability Issues 5(2): 297-314, https://doi.org/10.9770/jesi.2017.5.2(10)

Trubenová, D.; Ušiak, J. 2018. Význam malých a stredne vel'kých štátov pre Severoatlantickú alianciu [Importance of small and medium-sized states for the North Atlantic Alliance]. Liptovský Mikuláš: Akadémia ozbrojených síl generála M.R.Štefánika, s.469-477. ISBN 978-80-8040-568-7

Tvaronavičienė, M. 2018. Towards efficient policy making: forecasts of vulnerability to external global threats, Journal of Security and Sustainability Issues 7(3): 591-600 http://doi.org/10.9770/jssi.2018.7.3(18)

Tvaronavičienè, M.; Grybaite, V. 2012. Sustainable development and performance of institutions: approaches towards measurement, Journal of Security and Sustainability Issues 1(3): 167-175.

Tvaronavičienè, M.; Grybaitè,V.; Tvaronavičienè, A. 2009. If Institutional Performance Matters: Development Comparisons of Lithuania, Latvia and Estonia, Journal of Business Economics and Management 10(3): 271-278. http://doi.org/10.3846/1611$\underline{1699.2009 .10 .271-278}$

\section{Aknowledgements}

This research was supported by the outcome of the project "Analysis and Simulation of Information and Security Threats Workplace (PASIBO)", which has received funding from the European Union's Grant Agreement Number OPVaV2015/1.1/03-SORO, ITMS code 26210120044.

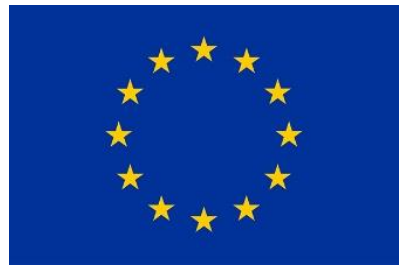


ENTREPRENEURSHIP AND SUSTAINABILITY ISSUES

ISSN 2345-0282 (online) http://jssidoi.org/jesi/

2019 Volume 6 Number 3 (March)

http://doi.org/10.9770/jesi.2019.6.3(29)

\begin{abstract}
About contributors:
Assoc. Prof. Rastislav KAZANSKÝ, PhD. MBA is a Head of the Department of Security Studies at the Faculty of Political Science and International Relations of Matej Bel University (MBU) in Banska Bystrica, where he conducts lectures, seminars and consultations both in daily and in external forms. At present, he is professionally involved in pedagogical and scientific research activities within the Geopolitics of Central European Region, Security Policy - Conflict Theory, Peace and Conflict Studies.
\end{abstract} ORCID ID: https://orcid.org/0000-0002-2701-2023

Dipl. Eng. Vladimír ANDRASSY, PhD. is a Senior Lecturer at the Department of Security and Defence of the Armed Forces Academy General Milan Rastislav Stefanik Liptovsky Mikulas. At present, he is professionally involved in pedagogical and scientific research activities within the Crisis management, Security, Crisis scenarios and Simulations.

ORCID ID: htpps://orcid.org/0000-0002-1207-300X

Register for an ORCID ID:

https://orcid.org/register

Copyright (C) 2019 by author(s) and VsI Entrepreneurship and Sustainability Center

This work is licensed under the Creative Commons Attribution International License (CC BY).

http://creativecommons.org/licenses/by/4.0/

c) (i) Open Access 